\title{
KAJIAN PENYAKIT YANG DISEBABKAN OLEH CENDAWAN PADA TANAMAN CABAI MERAH (Capsicum annum L.) DI PERTANAMAN RAKYAT KABUPATEN BREBES
}

\author{
Nita Wahyu SuWARdani, Purnomowati, EddY TRi SuCIanto
}

Fakultas Biologi, Universitas Jenderal Soedirman, Jalan dr. Suparno 63 Purwokerto 53122

\section{A B S T R A C T}

This research aimed to determine the various diseases caused by fungi, to identify the fungi causing the disease, and to determine the most dominant disease in red chili crops (Capsicum annum L.) from smallholder agriculture located in Kaligiri Sirampog Brebes. The research was a survey applying purposive random sampling technique. This study collected samples from five locations, within five plots placed diagonally at each site. This study picked ten infected plants from each plot, identified the disease; isolated and identified the fungi causing the disease. This research also measured the environmental factors such as temperature, humidity, and soil $\mathrm{pH}$. The results showed diseases in red chili plants (Capsicum annum L.) were the leaf spot caused by Cercospora sp., the anthracnose caused by Colletotrichum sp., and the fusarium wilt caused by Fusarium sp., and the most dominant were leaf spot disease.

KEY WORDS: Red chili (Capsicum annum L.), leaf spot, anthracnose, fusarium wilt

Corresponding Author: NITA WAHYU SUWARDANI | email: nitawahyuape@gmail.com

\section{PENDAHULUAN}

Tanaman cabai merah merupakan salah satu tanaman rempah-rempah yang memiliki nilai ekonomis yang cukup tinggi karena cabai merah selain digunakan sebagai bumbu masak juga dapat dimanfaatkan sebagai bahan obat-obaatan tradisional misalnya sebagai perangsang untuk meringankan perut kembung, sebagai obat luar bagi penderita sakit punggung, sakit kepala dan rematik (Djarwaningsih, 2005). Menurut Subagyono (2010) tanaman cabai merah merupakan tanaman perdu dengan rasa buah pedas yang disebabkan oleh kandungan capsaicin. Secara umum cabai merah memiliki banyak kandungan gizi dan vitamin, diantaranya kalori, protein, lemak, karbohidrat, kalsium, vitamin A, B1, dan vitamin C. Rizqi (2010) menambahkan selain itu juga mengandung mineral, seperti zat besi, kalium, kalsium, fosfor, dan niasin. Zat aktif capsaicin berkhasiat sebagai stimulan.

Kebutuhan cabai terus meningkat setiap tahun sejalan dengan meningkatnya jumlah penduduk dan berkembangnya industri yang membutuhkan bahan baku cabai. Tahun 2008 sampai saat ini produksi cabai di Indonesia diperkirakan mencapai 1,311 juta ton (meningkat 26,14\% dibandingkan tahun 2007, terdiri dari jenis cabai merah besar 798,32 ribu ton $(60,90 \%)$ dan cabai rawit 512,67 ribu ton $(39,10 \%)$. Daerah sentra produksi utama cabai merah antara lain Jawa Barat (Garut, Tasikmalaya, Ciamis, Sukabumi, Cianjur dan Bandung), Jawa Tengah (Brebes, Magelang, dan Temanggung), Jawa Timur (Malang, Banyuwangi). Sentra utama cabai keriting adalah Bandung, Brebes, Rembang, Tuban, Rejanglebong, Solok, Tanah Datar, Karo, Simalungun, Banyuasin, Pagar Alam (Subagyono, 2010).

Kabupaten Brebes merupakan salah satu sentra cabai merah di Indonesia, memasok sekitar lebih dari $30 \%$ kebutuhan cabai di Provinsi Jawa Tengah. Total produksi cabai Kabupaten Brebes pada tahun 2009 sebanyak 531.329 kuintal, terdiri dari cabai besar 417.913 kuintal dan cabai rawit sebanyak 113.416 kuintal dengan luas panen masing- masing sebesar 5.925 ha dan 2.086 ha. Produksi cabai di Brebes memiliki porsi $37,08 \%$ terhadap total produksi cabai provinsi Jawa Tengah atau $6,86 \%$ terhadap total produksi cabai nasional. Namun, bila dibandingkan periode November 2009 lalu, produksi cabai pada November 2010 cenderung mengalami penurunan $6,01 \%$, terdiri dari penurunan produksi cabai merah $3,96 \%$ dan cabai rawit 13,16\% (Bank Indonesia, 2010).

Faktor yang dapat menurunkan produktivitas cabai merah di Brebes adalah tanaman mengalami kebanjiran atau kekeringan. Beberapa penyakit yang sering dijumpai pada tanaman cabai merah di Brebes, selain disebabkan oleh virus juga dapat disebabkan oleh cendawan. Menurut Semangun (2007) penyakit pada tanaman cabai merah yang sering menimbulkan kerugian diantaranya adalah penyakit bercak daun, penyakit antraknosa, penyakit tepung, penyakit busuk leher akar, penyakit layu fusarium, dan penyakit rebah semai.

Upaya pengendalian penyakit pada tanaman cabai merah di Brebes telah banyak dilakukan oleh petani dengan menggunakan fungisida. Namun demikian upaya-upaya tersebut belum menunjukkan hasil yang memuaskan. Hingga saat ini kajian mengenai jenis-jenis penyakit terutama yang disebabkan oleh cendawan pada tanaman cabai merah yang terdapat di pertanaman rakyat di Kabupaten Brebes belum banyak dilakukan. Tujuan dari penelitian ini adalah mengetahui jenis penyakit yang disebabkan oleh cendawan pada tanaman cabai merah (C. annum L.) di pertanaman rakyat Kabupaten Brebes; mengetahui cendawan yang menyebabkan penyakit pada tanaman cabai merah (C. annum L.) di pertanaman rakyat Kabupaten Brebes; mengetahui penyakit yang 
paling dominan pada tanaman cabai merah (C.annum

L.) di pertanaman rakyat Kabupaten Brebes.

Penelitian ini diharapkan dapat memberikan informasi ilmiah tentang jenis-jenis penyakit yang disebabkan oleh cendawan pada tanaman cabai merah di pertanaman rakyat Kabupaten Brebes. Hasil dari penelitian ini dapat digunakan sebagai bahan pertimbangan dalam upaya pengendalian penyakit, sehingga dapat menurunkan tingkat kerugian produksi cabai merah akibat penyakit yang terdapat di Desa Kaligiri, Kecamatan Sirampog, Kabupaten Brebes.

\section{MET ODE}

Metode yang digunakan pada penelitian ini adalah metode survey pada pertanaman rakyat cabai merah di Desa Kaligiri, Kecamatan Sirampog, Kabupaten Brebes. Pengambilan sampel tanaman sakit dilakukan secara Purposive Sampling. Sampel diambil pada 5 lokasi berbeda. Setiap lokasi terdiri dari 5 petak sampel dan pada setiap petak sampel diambil 10 contoh tanaman sakit secara diagonal. Sehingga diperoleh 250 contoh tanaman sakit. Identifikasi penyakit tanaman dilakukan di Laboratorium Mikologi/Fitopatologi, Fakultas Biologi, Universitas Jenderal Soedirman. Identifikasi penyakit tanaman dilakukan menggunakan buku "Penyakit-Penyakit Tanaman Hortikultura di Indonesia" (Semangun, 2007) dan "Plant Disease Handbook" (Westcott, 1971).

Isolasi patogen dilakukan mengikuti cara isolasi patogen Agrios (1996), sebagai berikut:

a. Membuat beberapa potongan segi empat berukuran 5 sampai $10 \mathrm{~mm}$ dari sampel tanaman sakit. Potongan tersebut dibuat dari bagian tepi luka tanaman yang terinfeksi sehingga potongan tersebut mengandung jaringan yang sakit dan jaringan yang masih terlihat sehat.

b. Potongan-potongan tersebut dimasukkan ke dalam alkohol $70 \%$ untuk mensterilisasi permukaan selama kurang lebih 15 sampai 30 detik, hingga permukaan potongan tersebut cukup basah.

c. Setelah disterilisasi dengan alkohol $70 \%$, dicuci dengan aquades steril lalu dikeringkan dengan tisu steril.

d. Potongan-potongan tersebut ditempatkan pada medium PDA dan diinkubasi hingga tumbuh jamur.

e. Bila jamur sudah tumbuh, dimurnikan dalam biakan media baru. Kemudian dapat di identifikasi jamurnya.

Identifikasi cendawan patogen dilakukan dengan mencocokkan karakteristik cendawan yang diperoleh menggunakan buku kunci identifikasi dan determinasi Barnett dan Hunter (1972), Alexopoulos et al (1996), Domsch et al., (1993) dan Gandjar et al., (1999). Identifikasi cendawan dilakukan hingga tingkat genus.

\section{HASIL DAN PEMBAHASAN}

Penyakit yang terdapat pada tanaman cabai adalah penyakit bercak daun (Gambar 1B). Penyakit bercak daun memiliki gejala terdapatnya bercak-bercak bulat, kecil, kebasah-basahan pada daun. Bercak dapat meluas hingga memcapai garis tengah $0,5 \mathrm{~cm}$ atau lebih, bagian tengahnya pucat sedangkan tepinya berwarna lebih gelap. Bercak lama kelamaan dapat berlubang. Apabila terdapat banyak bercak pada daun, daun akan cepat menguning dan gugur, bahkan daun akan gugur juga tanpa menguning. Bercak juga dapat dijumpai pada batang, tangkai daun, maupun tangkai buah, tetapi jarang terdapat pada buah (Semangun, 2007).

Penyakit bercak daun tersebut disebabkan oleh jamur Cercospora sp. yang awalnya berupa bercak nekrotik kecil pada permukaan daun, lalu berkembang menjadi bercak tidak beraturan dan menghasilkan konidia dalam jumlah banyak Jika bercak ini terlalu banyak aktivitas fotosintesis akan terganggu dan menurunkan hasil panen cabai merah tersebut. Penyakit bercak daun Cercospora sp. dapat mengakibatkan kerusakan tanaman hingga 50\% lebih jika tidak dikendalikan (Moekasan dan Prabaningrum, 2012)

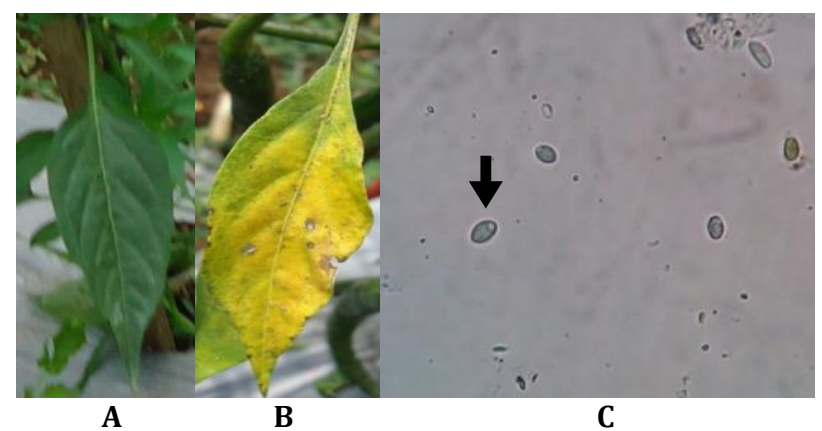

Gambar 1. A. Daun sehat. B. Daun terkena bercak daun. C. mikroskopis spora Cercospora sp. perbesaran 40×10

Jamur Cercospora sp. memiliki spora berwarna abu-abu dan berbentuk oval dengan panjang 40$60 \mu \mathrm{m}$ dan lebar 6-8 $\mu \mathrm{m}$ (Gambar 1C). Memiliki miselium yang berseptat dan berwarna hialin. Penyakit bercak daun yang disebabkan oleh Cercospora sp. sering terjadi di lahan pertanaman yang sangat lembab (kelembaban dapat lebih dari 90\%) (Yullia, 2011). Di lokasi pertanaman kelembaban 60-70\%, tetapi bercak daun cercospora sangat banyak ditemui. Suhu yang sesuai untuk perkembangan jamur Cercospora sp. ialah pada suhu $28-32^{\circ} \mathrm{C}$. Lokasi pertanaman memiliki suhu pada pagi berkisar $27^{\circ} \mathrm{C}$ dan sore hari sekitar $28^{\circ} \mathrm{C}$. Suhu di lokasi sesuai dalam membantu penyebaran spora untuk menginfeksi penyakit bercak daun cercospora.

Penyakit lain yang ditemukan di lokasi penelitian adalah penyakit antraknosa (Gambar 2B). Di Desa Sirampog penyakit antraknosa dikenal dengan istilah "pathek" yang sangat dibenci petani di sana. Sebab penyakit tersebut dapat membuat petani gagal panen. Penyebaran penyakit ini sangat cepat, apabila satu lahan terkena dapat mengenai lahan yang lain. Hampir satu lahan pada lokasi III dalam penelitian ini terkena antraknosa.

Penyakit antraknosa disebabkan oleh jamur Colletotrichum sp. dengan gejala mula-mula terbentuk bercak cokelat kehitaman, yang meluas menjadi busuk lunak. Di tengah bercak tersebut terdapat kumpulan titik-titik hitam yang terdiri dari seta dan konidium jamur (Kurniawan, 2011). Serangan yang berat menyebabkan seluruh buah mengering dan mengerut (keriput). Buah yang seharusnya berwarna merah menjadi berwarna seperti jerami. Jika cuaca 
kering jamur hanya membentuk becak kecil yang tidak meluas. Tetapi setelah buah dipetik dan kelembaban udara tinggi selama proses penyimpanan, jamur akan berkembang dengan cepat (Semangun, 2007).

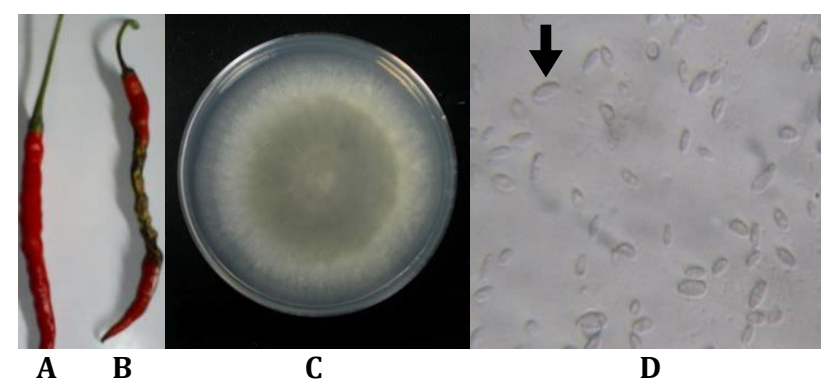

Gambar 2. A. Buah cabai sehat, B. Buah cabai terkena antraknosa, C. makroskopis jamur Colletotrichum sp., D. spora Colletotrichum sp. perbesaran $40 \times 10$.

Cendawan Colletotrichum sp. memiliki koloni dengan tekstur yang halus, warna koloni putih dan sporanya berwarna abu-abu (Gambar 2C). Bentuk sporanya silindris memiliki panjang $18-25 \mu \mathrm{m}$ dan lebar 3,5-5 $\mu \mathrm{m}$ (Gambar 2D). Miselium berseptat, berwarna hialin.

Perkembangan penyakit antraknosa sangat cepat apabila kondisi lingkungan lembab dan suhu relatif tinggi. Kelembaban di lokasi saat penelitian rata-rata 60-70\%. Suhu di sekitar pertanaman pada pagi hari berkisar $27^{\circ} \mathrm{C}$ dan sore hari $28^{\circ} \mathrm{C}$. Perkembangan bercak dari jamur Colletotrichum sp. paling baik terjadi pada kondisi suhu $30^{\circ} \mathrm{C}$ (Semangun, 2007). Penyakit antraknosa dapat berkembang secara baik di Desa Sirampog karena pada siang hari suhu dapat mencapai $30^{\circ} \mathrm{C}$.

Penyakit antraknosa pada tanaman cabai dapat menimbulkan kerugian bagi petani, sehingga seringkali petani memanen cabai sebelum waktunya atau sebelum masa panen. Petani di daerah Sirampog menyebutnya sebagai panen ijo. Selain di lahan, penyakit antraknosa terdapat juga pada buah cabai yang sudah di panen, yaitu selama dalam pengangkutan dan dalam penyimpanan. Cabai hasil panen akan busuk dan menimbulkan kerugian hingga 70\% (Efri, 2010).

Selain penyakit bercak daun dan antraknosa ditemukan juga penyakit layu yang disebabkan oleh jamur Fusarium sp.. Gejala layu fusarium pada tanaman cabai merah diawali dengan memucatnya tulang-tulang daun, terutama daun bagian atas, kemudian diikuti dengan merunduknya tangkai, dan akhirnya tanaman cabai merah menjadi layu secara keseluruhan (Semangun, 2007). Subagyono (2010) juga menyampaikan bahwa jamur Fusarium sp. menginfeksi dari akar lalu keseluruh tanaman, melalui pembuluh xylem sehingga mengganggu proses transport air dan penyerapan nutrisi pada tanaman dan akhirnya tanaman layu.

Fusarium sp. memiliki dua tipe spora yaitu makrokonidia dan mikrokonidia. Makrokonidia berbentuk bulan sabit dengan panjang 40-70 $\mu \mathrm{m}$ dan lebar 15-20 $\mu$ m ditemukan dalam jumlah lebih sedikit dari pada mikrokonidia (Gambar 3D). Mikrokonidia berbentuk oval, panjang 20-25 $\mathrm{m}$ dan lebar 15$20 \mu \mathrm{m}$. Memiliki miselium yang bersekat.

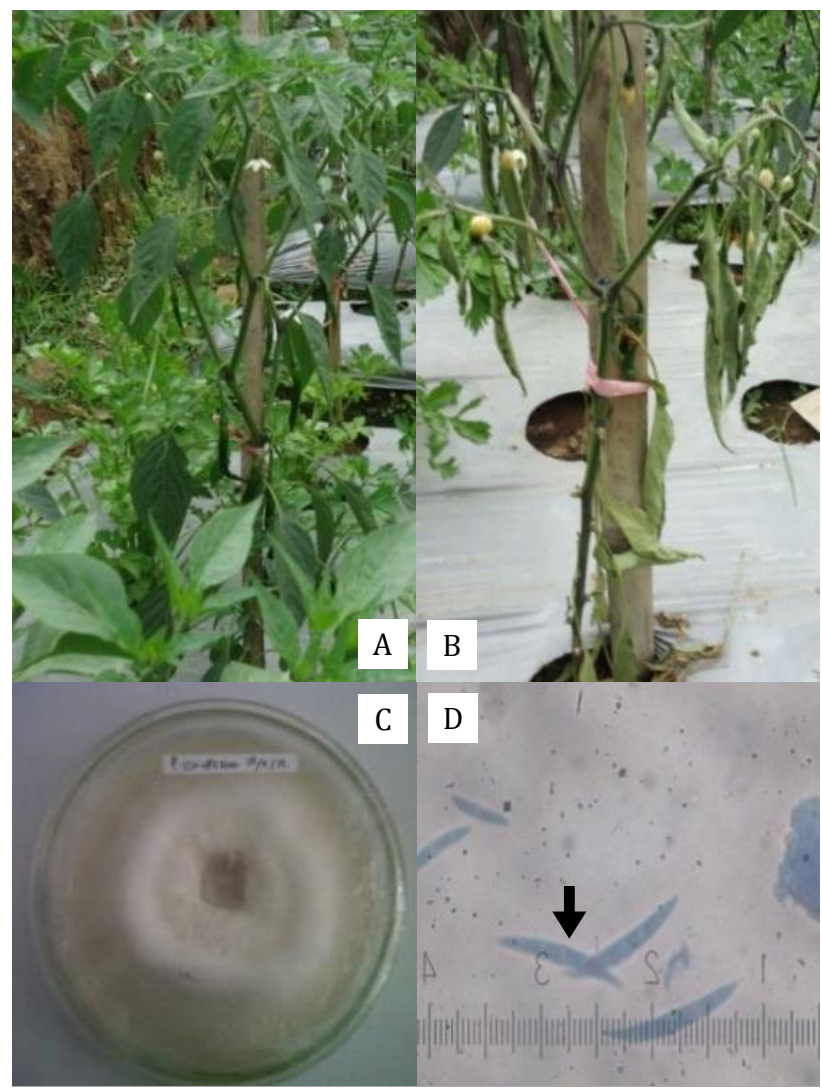

Gambar 3. A. Tanaman cabai sehat. B. Tanaman cabai gjala layu Fusarium. C. Makroskopis jamur Fusarium sp., D. makrokonida Fusarium sp. perbesaran 40 x 10

Jamur Fusarium sp. berkembang pada suhu tanah $21-33^{\circ} \mathrm{C}$. Suhu optimumnya $28^{\circ} \mathrm{C}$ (Semangun, 2007). Suhu pada lokasi juga dapat mencapai $28^{\circ} \mathrm{C}$ sehingga penyakit layu fusarium dapat lebih mudah berkembang pada tanaman cabai. Semangun (2007) menambahkan bahwa kelembaban juga membantu perkembangan penyakit layu fusarium selain suhu. Kelembaban pada lokasi berkisar antara 60-70\%. pH tanah di pertanam 6-7, sedangkan Fusarium sp. dapat hidup pada $\mathrm{pH}$ tanah yang luas variasinya.

Hasil pengamatan frekuensi kemunculan penyakit yang terdapat pada tanaman cabai merah menunjukkan bahwa penyakit bercak daun merupakan penyakit yang dominan. Sebab penyakit bercak daun ditemukan pada semua lokasi penelitian. Pada lokasi I frekuensi kemunculan sebanyak 22 kali, lokasi II 15 kali, lokasi III 6 kali, lokasi IV 34 kali dan lokasi V ditemukan 30 kali. Sedangkan penyakit antraknosa hanya ditemukan pada 4 lokasi yaitu lokasi I sebanyak 7 kali, lokasi III 44 kali, lokasi IV 12 kali dan lokasi V 5 kali. Layu fusarium hanya ditemukan pada 2 lokasi dari 5 lokasi yang digunakan untuk penelitian yaitu pada lokasi I sebanyak 3 kali dan lokasi II sebanyak 21 kali.

Dari hasil tersebut dapat terlihat bahwa penyakit yang dominan adalah penyakit bercak daun oleh 
Cercospora sp. Hal tersebut dapat dimengerti karena kondisi lingkungan sesuai untuk perkembangan dan penyebaran penyakit bercak daun. Suhu pada lokasi penelitian berkisar $27^{\circ} \mathrm{C}$ pada pagi hari dan sore hari berkisar $28^{\circ} \mathrm{C}$. Suhu pada lokasi sesuai untuk perkembangan penyakit bercak daun menurut Yullia (2011) karena pada suhu $28-32^{\circ} \mathrm{C}$ spora dari cendawan Cercospora sp. dapat berkembang dengan baik. Michereff et al., (2011) menambahkan bahwa suhu yang sesuai untuk perkembangan penyakit bercak daun ini berkisar di atas $25^{\circ} \mathrm{C}$ dan kelembaban hingga $90 \%$. Kelembaban yang tinggi dapat membantu pembebasan spora (Tantawi dan Lisnawita, 2009), kelembaban di lokasi dapat mencapai $70 \%$ pada pagi dan sore harinya. Semangun (2007) juga menyampaikan bahwa penyakit bercak daun dapat berkembang dibantu oleh cuaca yang panas dan basah. Di lokasi penelitian pada saat siang hari cuaca sangat panas dan bila sore hari seringkali hujan dan berkabut.

Penyakit bercak daun lebih banyak ditemukan karena menurut petani setempat penyakit bercak daun oleh Cercospora sp. kurang diperhatikan. Petani lebih memfokuskan terhadap pengendalian penyakit lain seperti antraknosa dan layu fusarium dengan penyemprotan fungisida dari awal penanaman. Sehingga penyakit antraknosa dan layu hanya ditemukan lebih sedikit dibandingkan penyakit bercak daun.

\section{KE S I M P UL A N SARA N}

Penyakit tanaman cabai merah (Capsicum annum L.) yang diperoleh di pertanaman rakyat di Desa Kaligiri, Kecamatan Sirampog, Kabupaten Brebes ialah bercak daun, antraknosa dan layu fusarium. Cendawan penyebab penyakit pada tanaman cabai merah $(C$. annum L.) di pertanaman rakyat Desa Kaligiri, Kecamatan Sirampog, Kabupaten Brebes ialah cendawan Cercospora sp., Colletotrichum sp., dan Fusarium sp. Penyakit tanaman cabai merah ( $C$. annum L.) yang paling dominan pada pertanaman rakyat di Desa Kaligiri, Kecamatan Sirampog, Kabupaten Brebes ialah penyakit bercak daun.

\section{DAFT AR REFERENSI}

Agrios GN. 1996. Ilmu Penyakit Tumbuhan Edisi Ketiga. Diterjemahkan oleh Munzir Busnia. 1996. Yogyakarta: Gadjah Mada University Press.

Alexopoulos, C.J., C.W Mims,. And M. Blackwell. 1996. Introductory Mycology. Fourth edition. John Wiley dan Sons, Inc. Canada.

Barnett, H.L and B.Hunter. 1972. Illustated General Of Imperfect Fungi Third Edition. Burgess Publishing.Company, Minnesote.

Bank Indonesia. 2010. Kajian Ekonomi Regional Provinsi Jawa Tengah Triwulan IV. Semarang. Jawa Tengah.

Djarwaningsih, T. 2005. Review: Capsicum spp. (Cabai): Asal, Persebaran dan Nilai Ekonomi. Lembaga Ilmu Pengetahuan Indonesia (LIPI). Bogor.

Domsch, K.H., Gams, W. and Anderson, T.H. 1993. Compendium of soil fungi. IHW-Verlag, Eching, Germany.

Efri, 2010. Pengaruh Ekstrak Berbagai Bagian Tanaman Mengkudu (Morinda citrifolia) Terhadap Perkembangan Penyakit Antraknosa Pada Tanaman Cabe (Capsicum annuum L.). J. HPT. Tropika. Vol. 10, No 1:52-58. Universitas Lampung. Bandar Lampung.

Gandjar, I., R.A Samson, Karin van Der Tweel Vermulen, A. Oetari., I. Santoso. 1999. Pengenalan Kapang Tropik Umum. Yayasan Obor Indonesia. Jakarta.

Kurniawan, E. 2011. Penyakit Antraknose Pada Tanaman Cabai Merah. Universitas Brawijaya Malang.

Michereff, S.J., Martins, R.B., Noronha, M.A., and Machado, L.P. 2011. Sample Size For Quantification of Cercospora Leaf Spot in Sweet Pepper. Journal of Plant Pathology. Brazil. 93(1), 183-186.

Moekasan, TK dan Prabaningrum, L. 2012. Penggunaan Rumah Kasa Untuk Mengatasi Serangan Organisme Pengganggu Tumbuhan Pada Tanaman Cabai Merah Di Dataran Rendah. J. Hort. 22 (1):65-75. Balai Penelitian Tanaman Sayuran. Lembang. Bandung.

Rizqi, D.N. 2010. Budidaya Tanaman Cabai Merah (Capsicum annum) di UPTD Pembibitan Tanaman

Semangun, H. 2007. Penyakit-penyakit Tanaman Hortikultura Di Indonesia. Gadjah Mada University Press. Yogyakarta.

Subagyono, Kasdi. 2010. Budidaya dan Pascapanen Cabai Merah (Capsicum annum L.).Badan Penelitian dan Pengembangan Pertanian Balai Pengkajian Teknologi Pertanian Jawa Tengah.

Tantawi, A.R. dan Lisnawita. 2009. Penangkapan Konidium Cercospora nicotianae Dengan Alat Penangkap Spora Di Perkebunan Tembakau Cerutu. Jurnal Pertanian \& Biologi. Agrobio/Volume 1/Nomer 1. Universitas Medan Area.

Westcott, C. 1971. Plant Disease Handbook. Third Ed. Van Nostrand Company Reinhold

Company. New York.

Yullia, T. 2011. Petunjuk Praktis Bertanam Cabai. Agro Media Pustaka. Jakarta. 